\title{
Congenital costal fusion can be misinterpreted as lesions on chest X-ray
}

\author{
Masaki Tago (ㄷ) , Hidetoshi Aihara, Motoshi Fujiwara, Shu-ichi Yamashita
}

Department of General Medicine, Saga University Hospital, Saga, Japan

\section{Correspondence to} Dr Masaki Tago; tagomas@cc.saga-u.ac.jp

Accepted 26 May 2021

\section{DESCRIPTION}

A 67-year-old man visited our hospital for fever lasting 1 week, sore throat and appetite loss. $\mathrm{He}$ was a current smoker (50 pack-years), had no other particular medical history and was taking no medications. On the first visit, he had no fever, abnormalities in vital signs or physical examination findings. Chest X-ray revealed opacity in the right fifth intercostal space in the right upper lung field, which suggested a mass lesion such as a bone primary tumour or metastasis (figure 1A). Chest CT showed fusion of the right fifth and sixth ribs, which led to a diagnosis of congenital costal fusion (figure 1B). Other examinations found no obvious abnormalities, and the patient was subsequently diagnosed with a viral infection and improved with symptomatic treatment.

Segmentation errors, including costal fusion and bridging, account for $26 \%$ of all congenital rib malformations. ${ }^{1}$ Costal fusion has reportedly been found in $0.3 \%$ of a sample of the general population. $^{2}$ Because congenital rib malformations are mostly asymptomatic, ${ }^{3}$ costal fusion is often found incidentally on chest X-ray, as in the present case. Rib malformations are frequently associated with a thoracic or thoracolumbar scoliosis. ${ }^{4}$ On the other hand, costal fusion frequently occurs in the first and second ribs, which can cause a thoracic outlet syndrome..$^{5}$ If opacity is seen in the intercostal space on chest X-ray, physicians should first carefully check the differences between the left and right sides of the intercostal space and rib cage on physical examination and chest X-ray rather than quickly perform CT under suspicion of mass lesions. In addition, the presence of thoracic or thoracolumbar scoliosis and symptoms of thoracic outlet

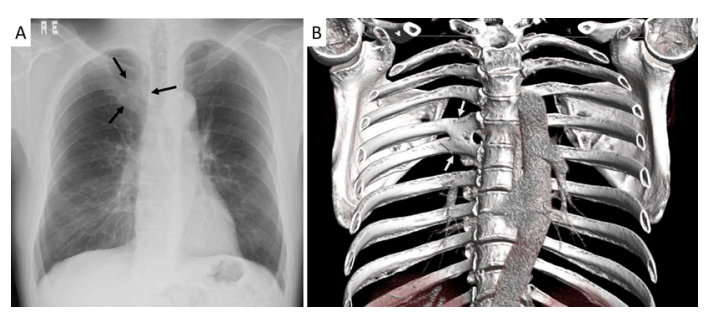

Figure 1 (A) Chest X-ray revealed opacity in the right fifth intercostal space in the right upper lung field (black arrows). (B) Reconstructed chest CT image showed fusion of the right fifth and sixth ribs (white arrows).

\section{Learning points}

- Congenital costal fusion can be misinterpreted as lesions on chest X-ray.

- Physicians should first carefully check the differences between the left and right sides of the intercostal space and rib cage on physical examination and chest $\mathrm{X}$-ray rather than quickly perform CT under suspicion of mass lesions.

syndrome could also be helpful for diagnosis. In this case, careful interpretation of the radiographs indicated that the right fifth intercostal space was narrower than that on the left. Not only radiologists but also physicians should be well familiarised with costal fusion, which is not uncommon, to make the correct diagnosis.

Acknowledgements We thank Richard Lipkin, PhD, from Edanz Group (https://en-author-services.edanz.com/) for editing a draft of this manuscript.

Contributors MT involved in concept, literature search and drafting. HA and MF involved in literature search and drafting. S-iY involved in concept and revision of article.

Funding The authors have not declared a specific grant for this research from any funding agency in the public, commercial or not-for-profit sectors.

Competing interests None declared.

Patient consent for publication Obtained.

Provenance and peer review Not commissioned; externally peer reviewed.

ORCID iD

Masaki Tago http://orcid.org/0000-0003-1092-1834

\section{REFERENCES}

1 Wattanasirichaigoon D, Prasad C, Schneider G, et al. Rib defects in patterns of multiple malformations: a retrospective review and phenotypic analysis of 47 cases. Am J Med Genet A 2003;122A:63-9.

2 Gupta V, Suri RK, Rath G. Synostosis of first and second thoracic ribs: anatomical and radiological assessment. Int J Anat Var 2009;2:131-3.

3 Guttentag AR, Salwen JK. Keep your eyes on the ribs: the spectrum of normal variants and diseases that involve the ribs. Radiographics 1999; 19:1125-42.

4 Tsirikos Al, McMaster MJ. Congenital anomalies of the ribs and chest wall associated with congenital deformities of the spine. J Bone Joint Surg Am 2005;87:2523-36.

To cite: Tago M, Aihara $\mathrm{H}$ Fujiwara M, et al. BMJ Case Rep 2021;14:e242834. doi:10.1136/bcr-2021242834
5 Reidler JS, Das De S, Schreiber JJ, et al. Thoracic outlet syndrome caused by Synostosis of the first and second thoracic ribs: 2 case reports and review of the literature. J Hand Surg Am 2014;39:2444-7. 
Images in...

Copyright 2021 BMJ Publishing Group. All rights reserved. For permission to reuse any of this content visit https://www.bmj.com/company/products-services/rights-and-licensing/permissions/

BMJ Case Report Fellows may re-use this article for personal use and teaching without any further permission.

Become a Fellow of BMJ Case Reports today and you can:

- Submit as many cases as you like

- Enjoy fast sympathetic peer review and rapid publication of accepted articles

Access all the published articles

Re-use any of the published material for personal use and teaching without further permission

Customer Service

If you have any further queries about your subscription, please contact our customer services team on +44 (0) 2071111105 or via email at support@bmj.com.

Visit casereports.bmj.com for more articles like this and to become a Fellow 